\title{
FLAVONOIDS AND ANTIMICROBIAL ACTIVITY OF LEAVES OF XYLOSMA LONGIFOLIUM
}

\author{
MEHTAB PARVEEN* AND RAZA MURAD GHALIB
}

Department of Chemistry, Aligarh Muslim University, Aligarh, 202002.UP, India

(Received: March 17, 2011 - Accepted: September 9, 2011)

\begin{abstract}
The methanolic extract of the leaves of Xylosma longifolium afforded a new flavonodic compound named as Kaempferol-3- $\beta$-xylopyranoside-4'- $\alpha$-rhamnoside along with Kaempferol, Quercetin, Kaempferol-3-rhamnoside, Quercetin-3-rhamnoside. Their structures were established on the basis of chemical and physical evidences (IR, ${ }^{1} \mathrm{H} N M R$, and MS data). It was also screened for their antimicrobial activity.
\end{abstract}

Keywords: Xylosma longifolium, flacourtiaceae, flavonoids, antimicrobial activity.

\section{INTRODUCTION}

The genus Xylosma, a large genus of shrubs and trees is chiefly distributed in most of the tropical and subtropical regions. About four species are found in India. ${ }^{1}$ It occurs as shady ravines of the western Himalayas from Kashmir to Kumaon and on low hills up on to an altitude of 1,500 meter. The extract of Xylosma longifolium (Commonly know as "Khandhara") leaves is found to resembles opium in its action and is used with it for house pests and fences. It is used in Assam for intoxication, and also exhibits antispasmodic, dysentery, restlessness and insomnia. ${ }^{1,2}$ It is grown in India for its edible fruits. ${ }^{3}$ Medicinal importance of $X$. longifolium and scanty of work on it encourages us to carry out the comprehensive investigation of the leaves of $X$. longifolium. Earlier investigation on this plant includes the isolation and characterization of $\beta$-sitosterol, $\beta$ - amyrin, friedelin, olean-12-en-3 $\alpha$-ol-28-oic acid $3 \alpha-\mathrm{D}$ glucopyranoside ${ }^{4}$. Now we are reporting the isolation and characterization of a novel flavonoid kaempferol-3- $\beta$-xylopyranoside-4'- $\alpha$-rhamnoside along with the known flavonoids kaempferol, ${ }^{5}$ quercetin, ${ }^{6}$ kaempferol-3-rhamnoside, ${ }^{7}$ quercetin-3-rhamnoside ${ }^{8}$ which have not been reported so far from this plant.

\section{EXPERIMENTAL}

\section{General experimental procedure}

The melting points were taken on a Koefler block and are uncorrected. ${ }^{1} \mathrm{H}$ NMR spectra were recorded on Bruker Avance II $400 \mathrm{MHz}$ with TMS as an internal standard. IR spectra were run on Shimadzu IR-408 Perkin-Elmer 1800 (FTIR). The MS were measured in both EI Mode and Jeol D-300 and FAB mode on Jeol SX 102/ DA-6000 mass spectrometers.

\section{Plant material}

The leaves of Xylosma longifolium collected from Forest Research Institute, Dehradun in winter season and identified by Prof. Wazahat Hussain, Taxonomist, Department of Botany, Aligarh Muslim University, Aligarh, India.

Extraction and isolation

The leaves of Xylosma longifolium were dried under shade and crushed to make powder. The air dried powdered leaves $(2.5 \mathrm{~kg})$ were thoroughly extracted with light petroleum ether $\left(60-80^{\circ} \mathrm{C}\right)$, benzene and methanol successively. The methanolic extract responded positively to color test for flavonoid. TLC examination of the methanolic extract in different solvent systems [benzenepyridine-formic acid (36:9:5) and toluene-ethyl formate-formic acid (5:4:1)] showed it to be a complex mixture of five major compounds. They were tried to purify into individual components through column chromatography over silica gel. The column was eluted successively with benzene, benzeneethyl acetate (9:1-1:1) mixture, ethyl acetate, ethyl acetate-methanol (9:1-1:1) mixtures and finally with methanol. The purity of the fraction was monitored by TLC examination and infrared spectral studies. The fractions which showed similar behavior on TLC and same IR spectra were mixed together. Repeated column chromatography of the fractions followed by fractional crystallization furnished five crystalline homogenous compounds, labeled as XI- 1, 2, 3, 4 and $\mathbf{5}$.

Compound XI- 1

It was eluted with ethyl acetate-methanol (9:1) and crystallized from chloroform-methanol as yellow shinning crystals $(110 \mathrm{mg}) \mathrm{m} . \mathrm{p} .276-78^{\circ} \mathrm{C}$. The compound $\mathbf{X I}-\mathbf{1}$ is identified as kaempferol by mixed m.p., and superimposed IR, 1H NMR, UV data and comparison with authentic sample 5 .

\section{Acetylation of XI-1}

The crystalline compound XI-1 (20 mg) was acetylated by heating with pyridine $(2 \mathrm{ml})$ and acetic anhydride $(4 \mathrm{ml})$ on water bath for about 4 hours. It was cooled to room temperature and poured over crushed ice. The separated solid was filtered, washed with distilled water, dried and it was crystallized with chloroform-methanol, to yield yellow colorless needles of XI-1 Ac m.p. 180-82 ${ }^{\circ} \mathrm{C} .{ }^{1} \mathrm{H}$ NMR $\left(400 \mathrm{MHz}, \mathrm{CDCl}_{3}\right): \delta: 2.3(9 \mathrm{H}, \mathrm{s}, 3 \times \mathrm{OAc}), 2.4(3 \mathrm{H} \mathrm{s}, 1$ x OAc), $6.80(1 \mathrm{H}, \mathrm{d}, \mathrm{J}=2.0 \mathrm{~Hz}, \mathrm{H}-6), 7.0(1 \mathrm{H}, \mathrm{d}, \mathrm{J}=2.0 \mathrm{~Hz}, \mathrm{H}-8), 7.3(2 \mathrm{H}, \mathrm{d}$,

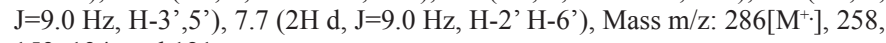
153,134 , and 121 .

\section{Compound XI-2}

Further elution of the column with ethyl acetate-methanol in ratio $(8: 2)$ gave a fraction which on crystallization with chloroform-methanol yielded the compound $\mathbf{X l - 2}$ as yellow shinning crystals $(120 \mathrm{mg}) \mathrm{m} . \mathrm{p} ., 311-12^{\circ} \mathrm{C}$. Its identity as quercetin was established by comparison of its spectral data with an authentic sample ${ }^{6}$.

\section{Acetylation of $\mathrm{XI}-2$}

The compound Xl-2 $(20 \mathrm{mg})$ was heated with pyridine $(1 \mathrm{ml})$ and acetic anhydride $(2 \mathrm{ml})$ on water bath for about 4 hours. After usual work up by the procedure described earlier followed by crystallization chloroform-methanol, it afforded yellow colored crystals Xl-2Ac, m.p. $194-95^{\circ} \mathrm{C} .{ }^{1} \mathrm{H}$ NMR $(400$ $\left.\mathrm{MHz}, \mathrm{CDCl}_{3}\right): \delta: 2.35(12 \mathrm{H}, \mathrm{m}, 4 \mathrm{x} \mathrm{OAc}), 2.38(3 \mathrm{H}, \mathrm{s}, 1 \mathrm{x} \mathrm{OAc}), 6.79(1 \mathrm{H}$, $\mathrm{J}=2.5 \mathrm{~Hz}, \mathrm{H}-6), 7.21(1 \mathrm{H}, \mathrm{d}, \mathrm{J}=2.5 \mathrm{~Hz}, \mathrm{H}-8), 7.26(1 \mathrm{H}, \mathrm{d}, \mathrm{J}=9.0 \mathrm{H},-5$ ') $7.62(\mathrm{q}$, $\left.\mathrm{J}_{1}=2.5 \mathrm{~Hz}, \mathrm{~J}_{2}=9.0 \mathrm{~Hz}, \mathrm{H}-6^{\prime}\right), 7.70\left(1 \mathrm{H}, \mathrm{d}, \mathrm{J}=2.5 \mathrm{~Hz}, \mathrm{H}-2^{\prime}\right)$.

\section{Compound $\mathrm{XI}-3$}

Elution the column with ethyl acetate-methanol (7:3) gave fraction which on crystallization with chloroform-methanol afforded yellow granular crystals $(100 \mathrm{mg}) \mathrm{m} . \mathrm{p} ., 177-78^{\circ} \mathrm{C}$. It gave positive Molish test and brownish green colour with alcoholic ferric chloride and identified Kaemferol-3-rhamnoside by comparison of spectral data with that of authentic sample ${ }^{7}$. Compound $\mathbf{X I - 3}$ $(20 \mathrm{mg})$ was acetylated with $\mathrm{Ac}_{2} \mathrm{O}(3.0 \mathrm{ml})$ \& pyridine $(1.50 \mathrm{ml})$ by heating on water bath for two hrs. After usual workup followed by crystallization with chloroform-methanol afforded colorless needles, m.p. $159-60^{\circ} \mathrm{C} .{ }^{1} \mathrm{H}$ NMR $(400$ $\mathrm{MHz}, \mathrm{CDCl}_{3}$ ): $\delta: 7.79\left(2 \mathrm{H}, \mathrm{J}=9.0 \mathrm{~Hz}, \mathrm{H}-2^{\prime}, 6^{\prime}\right), 6.90$ (2H, $\left.\mathrm{d}, \mathrm{J}=9.0 \mathrm{~Hz}, \mathrm{H}-3^{\prime}, 5^{\prime}\right)$, $6.38(1 \mathrm{H}, \mathrm{d}, \mathrm{J}=2.5 \mathrm{~Hz}, \mathrm{H}-8), 6.20(1 \mathrm{H}, \mathrm{d}, \mathrm{J}=2.5 \mathrm{~Hz}, \mathrm{H}-6), 5.21(1 \mathrm{H}, \mathrm{d}, \mathrm{J}=2.0 \mathrm{~Hz}$, $\mathrm{H}-1$ " rhamnosyl), 3.24-5.09 (4H, m, sugar protons), 2.32, 2.34, 2.45, (9H, each singlet, aromatic acetoxyls), 1.9-2.12 (9H, m, aliphatic acetoxyls), $0.87(3 \mathrm{H}, \mathrm{d}$, $\mathrm{J}=6.0 \mathrm{~Hz}$, rhamnosyl methyl).

\section{Compound Xl-4}

The compound Xl-4 was eluted from the column with ethyl acetatemethanol (7:3) and crystallized from chloroform-methanol as yellow

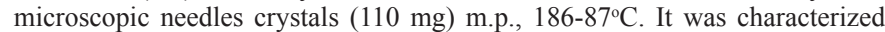
as Quercetin-3-rhamnoside by mixed m.p., IR, ${ }^{1} \mathrm{H}$ NMR, and comparison with authentic sample ${ }^{8}$. It was acetylated by above mentioned procedure and crystallized with $\mathrm{CHCl}_{3}-\mathrm{MeOH}$ as colorless needles m.p. 302-303 ${ }^{\circ} \mathrm{C}$. ${ }^{1} \mathrm{H}$ NMR $\left(400 \mathrm{MHz}, \mathrm{CDCl}_{3}\right): \delta: 7.40(1 \mathrm{H}, \mathrm{q}, \mathrm{J}=2.1 \mathrm{~Hz}$, and $9.0 \mathrm{~Hz} \mathrm{H}-6$ ' $), 7.20(1 \mathrm{H}, \mathrm{d}$, $\mathrm{J}=2.50 \mathrm{~Hz}, \mathrm{H}-2$ '), $7.10\left(1 \mathrm{H}, \mathrm{d}, \mathrm{J}=9.0 \mathrm{~Hz}, \mathrm{H}-5^{\prime}\right), 6.70(1 \mathrm{H}, \mathrm{d}, \mathrm{J}=2.1 \mathrm{~Hz}, \mathrm{H}-8)$, $6.51(1 \mathrm{H}, \mathrm{d}, \mathrm{J}=2.1 \mathrm{~Hz}, \mathrm{H}-6$ '), $5.40(1 \mathrm{H}, \mathrm{d}, \mathrm{J}=2 \mathrm{~Hz}, \mathrm{H}-1$ "), 3.30-5.70 (sugar protons, m, H-2", 3", 4",5"), 2.52-2.90 (12H, m, OAc-3',4',5,7), 1.90-2.21 
(9H, m, OAc-aliphatic), 0.86 (3H, d, J=6.5 Hz, rhamnosyl methyls). Compound XI-5 (I)

It was obtained from ethyl acetate-methanol (4:6-1:1) eluates and crystallized with methanol-chloroform as pale yellow granular crystals $(110$ mg) m.p. $265-67^{\circ} \mathrm{C}$. Analysed for $\mathrm{C}_{26} \mathrm{H}_{28} \mathrm{O}_{14}$ : Calcd: C, 56.11; H, 5.03\%, Found: C, 56.14; H, 5.07\%, UV $\lambda$ nm: 240sh. 269, 306sh, $345(\mathrm{MeOH})$, $245 \mathrm{sh}, 312,305 \mathrm{sh}, 340,398\left(\mathrm{AlCl}_{3}\right), 277,304,340,396,\left(\mathrm{AlCl}_{3} / \mathrm{HCl}\right), 281$, $355,370,(\mathrm{NaOAc}), 279,325 \mathrm{sh}, 365\left(\mathrm{NaOAc} / \mathrm{H}_{3} \mathrm{BO}_{3}\right), 255 \mathrm{sh}, 296,355,405$, (NaOMe)

\section{Acetylation of Xl-5:}

The crystalline glycoside $(45 \mathrm{mg})$ was acetylated with dry $\mathrm{Ac}_{2} \mathrm{O} / \mathrm{py}(1: 1)$ at room temperature for $48 \mathrm{hrs}$. After workup by the procedure described earlier, it was crystallized with chloroform-methanol as cream needles, m.p. $126-28^{\circ} \mathrm{C}$. ${ }^{1} \mathrm{H}$ NMR (400 MHz, $\mathrm{CDCl}_{3}$ ): $\delta: 6.80(1 \mathrm{H}, \mathrm{d}, \mathrm{J}=2.2 \mathrm{~Hz}, \mathrm{H}-6), 7.10(1 \mathrm{H}, \mathrm{d}, \mathrm{J}=2.20$ Hz, H-8), 7.89 (2H, d, J=8.50 Hz, H-2',6'), 7.26 (2H, d, J=8.5 Hz, H-3', 5'), $5.15(1 \mathrm{H}, \mathrm{d}, \mathrm{J}=9.50 \mathrm{~Hz}, \mathrm{H}-1$ "” xylose), $5.60(1 \mathrm{H}, \mathrm{d}, \mathrm{J}=1.2 \mathrm{~Hz}, \mathrm{H}-1$ ” rham $)$, $1.20\left(3 \mathrm{H}, \mathrm{d}, \mathrm{J}=6.1 \mathrm{~Hz}\right.$, rham- $\left.\mathrm{CH}_{3}\right), 3.77-5.60(10 \mathrm{H}, \mathrm{m}$, gly- $\mathrm{H}), 2.45(3 \mathrm{H}, \mathrm{s}, \mathrm{OAc}-$ 5), $2.34(3 \mathrm{H}, \mathrm{s}, \mathrm{OAc}-7), 1.98-2.20\left(18 \mathrm{H}, \mathrm{m}\right.$, aliphatic OAc), Mass m/z: $\mathrm{M}^{+}$ absent, $642\left[\mathrm{M}^{+} \text {-acetylated pentose }+\mathrm{H}^{+}\right]^{+}, 628\left[\mathrm{M}^{+} \text {-acetylated hexose }+\mathrm{H}^{+}\right]^{+}$, $370\left[\mathrm{M}^{+} \text {-acetylated pentose-acetylated hexose }+2 \mathrm{H}^{+}\right]^{+}, 286\left[\mathrm{M}^{+}-614\right]^{+}, 273$ $\left[(\text { rham }) \mathrm{Ac}_{3}\right]^{+}, 259\left[(\mathrm{xyl}) \mathrm{Ac}_{3}\right]^{+}, 153\left[\mathrm{~A}_{1}+\mathrm{H}\right]^{+}, 121\left[\mathrm{~B}_{2}\right]^{+}$.

Acid hydrolysis of XI-5:

The glycoside Xl-5 was hydrolyzed with 2N HCl-MeOH $(5 \mathrm{ml})$, (100 ${ }^{\circ} \mathrm{C}$, refluxed for $2 \mathrm{hr}$ ). Water was added and the mixture was extracted with ethylacetate. The aqueous hydrolysate was neutralized with $\mathrm{Ag}_{2} \mathrm{CO}_{3}$, precipitate filtered off and filtrate was evaporated in vacuo giving a residue.

\section{Identification of aglycone:}

The aglycone in EtOAc fraction was crystallized from $\mathrm{CHCl}_{3}-\mathrm{MeOH}$ as yellow needles, m.p. $280-81{ }^{\circ} \mathrm{C}$ and identified as Kaempferol by spectral and chromatographic comparison with authentic sample ${ }^{5}$. Analyzed for $\mathrm{C}_{15} \mathrm{H}_{10} \mathrm{O}_{6}$ Calcd: C, 62.93; H, 3.49\%, Found: C, $62.88 ; \mathrm{H}, 3.45 \%$. UV $\lambda_{\max } \mathrm{nm}: 249 \mathrm{sh}$, 267, 295sh, 330sh, $370(\mathrm{MeOH}), 260 \mathrm{sh}, 268,300 \mathrm{sh}, 364,421\left(\mathrm{AlCl}_{3}\right), 260 \mathrm{sh}$, $267,301 \mathrm{sh}, 365,423\left(\mathrm{AlCl}_{3} / \mathrm{HCl}\right), 260 \mathrm{sh}, 282,316,432(\mathrm{NaOMe}), 278,301$, 399 ( $\mathrm{NaOAc})$

\section{Identification of sugars:}

The neutral hydrolysate was concentrated and chromatographed on whatman No.1 filter paper using n-BuOH-acetic acid-water (4:1:5) and EtOAc-Pyridine- $\mathrm{H}_{2} \mathrm{O}(2: 1: 2)$ as solvent systems, employing the descending techniques. Authentic sugars were used as checks. The chromatograms were run for 24 hours and after drying at room temperature, they were sprayed with aniline phthalate and p-anisidine phosphate solutions. The chromatograms on drying at $100-05^{\circ} \mathrm{C}$, showed the presence of only rhamnose $(0.37,0.28)$ and xylose $(0.30,0.22)$.

\section{GLC of TMSi ether of sugars:}

The TMSi ether of sugars was obtained by taking $15 \mathrm{mg}$ of sugar in dry pyridine $(0.5 \mathrm{ml})$ and hexamethyldisilazane $(0.2 \mathrm{ml})$ in a $10 \mathrm{ml}$ round bottom flask. To this solution $(0.2 \mathrm{ml})$ of trimethyl chlorosilane was added and flask was stoppered and allowed to stand at room temperature for 45 minutes. The solution was then dried and taken in heptane. The heptane soluble TMSi ether derivatives of sugar were then subjected to GLC ( $2 \%$ OV-1, column temp. 150 $250^{\circ} \mathrm{C}, 10 \mathrm{~min}$. dect. temp. $300^{\circ} \mathrm{C}, \mathrm{N}_{2} 50 \mathrm{ml} / \mathrm{min}$ ) along with silyl derivatives of standard sugars $\left(\mathrm{R}_{\mathrm{f}} 3.9,3.8 \mathrm{~min}\right.$ for rhamnose, $3.9,4.5 \mathrm{~min}$ for xylose). The observed Rt-values were in agreement with those of an authentic sample of rhamnose and xylose.

\section{Enzymatic hydrolysis of XI-5:}

A mixture of compound Xl-5 (100 mg) and $\alpha$-rhamnosidase (contain $\alpha$-pectinase) $(10 \mathrm{mg})$ was incubated in $\left(\mathrm{NH}_{4}\right)_{2} \mathrm{SO}_{4}-\mathrm{NaOAc}$ buffer $(\mathrm{pH} 5.0)$ at $250^{\circ} \mathrm{C}$ for $30 \mathrm{hrs}$ and then after addition of water, it was extracted with $\mathrm{n}-\mathrm{BuOH}$. The $\mathrm{n}-\mathrm{BuOH}$ extract was chromatographed on silica gel column to give a partial glycoside, m.p. $254-56^{\circ} \mathrm{C}$, identified as kaempferol-3-O xyloside. From the $\mathrm{H}_{2} \mathrm{O}$ layer, L-rhamnose was identified by PC (n-butanol: acetic: water, 4:1:5).

\section{Methylation of Partial glycoside:}

$\mathrm{CH}_{3} \mathrm{I}(1 \mathrm{ml})$ and $\mathrm{Ag}_{2} \mathrm{O}(30 \mathrm{mg})$ were added to a solution of partial glycoside $(30 \mathrm{mg})$ in DMF $(3 \mathrm{ml})$. The mixture was stirred in dark at room temperature for 48 hours. The contents were filtered and the residue washed with little DMF. The filtrate was evaporated to dryness and the syrupy residue was hydrolysed with ethanol $(25 \mathrm{ml})$. The alcohol was recovered and the syrupy residue was hydrolysed with $2 \mathrm{~N} \mathrm{HCl}$. On usual workup it gave 3-OH, 5,7,4'-trimethoxy flavone (14 mg) m.p. $135-36^{\circ} \mathrm{C}$. Analysed for $\mathrm{C}_{18} \mathrm{H}_{16} \mathrm{O}_{6}$, calcd: C, $65.85 ; \mathrm{H}$, 4.87, Found: C, $65.91 ; \mathrm{H}, 4.92 \%$.

Quantitative estimation of sugars:

The anhydrous glycoside $(25 \mathrm{mg})$ was hydrolysed by refluxing with 0.2
$\mathrm{N} \mathrm{HCl}$. After cooling over night, the aglycone was dried and weighed (11.5 $\mathrm{mg}$ ), the ratio of aglycone to glycoside is $44.2 \%$ indicating the presence of two moles of sugar/mole of aglycone.

\section{Antimicrobial Activity}

The in vitro antimicrobial activity was carried out against Escherichia coli, Staphylococcus aureus, Salmonella typhimurium, Bacillus subtilis and in vitro antifungal activity was carried out against Candida albicans, Fusarrium oxysporum, Penicillium notatum, Aspergillus niger and Trichoderma viridae. The agar well diffusion method $^{9,10}$ was used $0.1 \mathrm{ml}$ of diluted inoculum $\left(10^{5} \mathrm{CFU} / \mathrm{ml}\right)$ of test organism was spread on Mueller Hinton Agar plates (HiMidia Pvt. Ltd., Mumbai, India). The wells of $8 \mathrm{~mm}$ diameter were punched into the agar medium and filled with $100 \mu \mathrm{l}$ of plant extract and some plant product of $1 \mathrm{mg} / \mathrm{ml}$ concentration and solvent blank (DMSO) separately. The plates were incubated at $37^{\circ} \mathrm{C}$ overnight. The antibiotic (Chloramphenicol) and antifungal disc (Nystatin) of $30 \mathrm{mcg}$ potency each were used in the system as positive controls. Zone of inhibition of bacterial and fungal growth around each well was measured in $\mathrm{mm}$.

\section{RESULT AND DISCUSSION}

The air dried powdered leaves of Xylosma longifolium ( $2.5 \mathrm{~kg}$ ) after being defatted with light petroleum ether $\left(60-80^{\circ} \mathrm{C}\right)$ were thoroughly extracted with benzene and methanol successively. The methanolic extract gave a color test for flavonoid and showed a intricate mixture of five major compounds on TLC [benzene-pyridine-formic acid (36:9:5) and toluene-ethyl formate-formic acid $(5: 4: 1)$ ]. It was purified through column chromatography over silica gel. Elution of the column with different solvent system such as benzene: benzeneethyl acetate (9:1-1:1) mixture, ethyl acetate, ethyl acetate-methanol (9:1-1:1) mixtures and methanol gave various fractions. The purity of the each fraction was monitored by TLC examination and infrared spectral studies. Appropriate fractions which showed similar behavior on TLC and IR spectra were pooled together. Repeated column chromatography of the fractions followed by fractional crystallization furnished five crystalline homogenous compounds, marked as XI 1-5. The compounds XI 1-4 were identified as Kaempfero, ${ }^{5}$ Quercetin, ${ }^{6}$ Kaempferol-3-rhamnoside, ${ }^{7}$ Quercetin-3-rhamnoside ${ }^{8}$ respectively, while the compound $\mathbf{X I - 5}$ was found to be a novel compound and characterized as Kaempferol-3- $\beta$-xylopyranoside-4'- $\alpha$-rhamnoside which is discussed below. The compound XI-5 was obtained from ethyl acetate-methanol (4:6-1:1) and crystallized with methanol-chloroform as pale yellow granular crystals $(110 \mathrm{mg}) \mathrm{mp} .265-67^{\circ} \mathrm{C}$. The glycosidic nature of $\mathbf{X I - 5}$ was evidenced by the positive Molish test obtained after hydrolysis and the formation of an osazone. Its was further confirmed by the ${ }^{1} \mathrm{H}$ NMR spectrum of the acetate of Xl-5 as it showed two aromatic acetoxyls at $\delta 2.45(3 \mathrm{H})$ and $\delta 2.34(3 \mathrm{H})$ and six aliphatic acetoxlys at $\delta 1.98-2.20(18 \mathrm{H}, 6 \times \mathrm{OAc})$ indicating it to be diglycoside. The glycoside gave pink colour with $\mathrm{Zn} / \mathrm{HCl}$ and red color on treatment with sodium amalgam followed by acidification ${ }^{11}$ indicating its flavonone or flavone nature. A yellow color with Wilson boric acid reagent ${ }^{6}$, ${ }^{12}$ and maxima at 240sh, 269, 306sh, 345 in the UV spectrum indicated it to be a flavonol glycoside. It gave brownish green color with $\mathrm{FeCl}_{3}$ pointing out the presence of hydroxyl group at $\mathrm{C}-5$. The IR spectrum showed strong absorption bands at $3450(\mathrm{OH}), 1665(\mathrm{C}=\mathrm{O}), 2950(\mathrm{C}-\mathrm{H}), 1645(\mathrm{C}=\mathrm{C}$, aromatic $)$ and broad band at $1105-1000 \mathrm{~cm}^{-1}$ supporting its glycosidic nature. A bathochromic shift of $+43 \mathrm{~nm}$ in band I with $\mathrm{AlCl}_{3}$ further confirmed the presence of a free 5-OH group. The presence of 7-OH group is confirmed by a bathochromic shift +12 $\mathrm{nm}$ in band II with fused NaOAc. Total acid hydrolysis of the glycoside with $2 \mathrm{~N}$ $\mathrm{HCl}$ yielded equimolor mixture of L- rhamnose, and D-xylose (PC and GLC) and an aglycone, (1b) m.p., $280-81^{\circ} \mathrm{C}$ which characterized as kaempferol (1b) by spectral and chromatographic comparison with authentic sample. ${ }^{13}$<smiles>[R10]Oc1cc([R20])cc2oc(-c3ccc([R16])cc3)c([R20])c(=O)c12</smiles>

(a) $\mathbf{R}_{1}, \mathbf{R}_{2}=\mathrm{H}, \mathbf{R}_{3}=$ rham, $\mathbf{R}_{4}=$ xyl.

(b) $\mathbf{R}_{1}, \mathbf{R}_{2}, \mathbf{R}_{3}, \mathbf{R}_{4=} \mathbf{H}$

(c) $\mathbf{R}_{1}, \mathbf{R}_{2}, \mathbf{R}_{3}=\mathbf{H}, \mathbf{R}_{4=} \mathbf{x l y}$.

d) $\mathbf{R}_{1}, \mathbf{R}_{2}, \mathbf{R}_{3}=\mathbf{C H}_{3}, \mathbf{R}_{4}=\mathbf{H}$

Acetylation of $\mathbf{X l}_{-5}$ with $\mathrm{Ac}_{2} \mathrm{O}$ and pyridine afforded octa-acetate $\mathbf{X I - 5}$ Ac 
m.p., 126-28 ${ }^{\circ} \mathrm{C}$. The ${ }^{1} \mathrm{H}$ NMR spectrum of XI-5 Ac, showed two meta coupled doublets at $\delta 6.80$ and $7.10(\mathrm{~J}=2.20 \mathrm{~Hz})$ were attributed to C-6 and C-8 proton respectively, Two ortho-coupled doublets at $\delta 7.89(\mathrm{~J}=8.5 \mathrm{~Hz})$ and $\delta 7.26(\mathrm{~J}=8.5$ $\mathrm{Hz}$ ) which corresponded to $\mathrm{A}_{2} \mathrm{~B}_{2}$ pattern were assigned to $\mathrm{C}-2^{\prime}, 6^{\prime}$, and $\mathrm{C}-3^{\prime}, 5^{\prime}$ ' proton of B-ring respectively. The anomeric proton at $\delta 5.15(\mathrm{~J}=9.5)$ and $\delta 5.60$ $(\mathrm{J}=1.2 \mathrm{~Hz})$ were assigned to $\mathrm{H}-1$ " " xylose ( $\beta$-configuration) and $\mathrm{H}-1$ " rhamnose ( $\alpha$-configuration) respectively. The rhamnosyl methyl appeared as a doublet at $\delta 1.20(6.0 \mathrm{~Hz})$. The remaining sugar protons were observed in the range $\delta$ 3.77-5.60. The mass spectrum of the acetylated glycoside (Scheme-I) was in agreement with the above assigned structure of the glycoside. The molecular ion as expected was not observed, the mass spectrum showed the presence of acetylated pentapyranoside, $\mathrm{m} / \mathrm{z} 259$ and acetylated hexopyranoside, $\mathrm{m} / \mathrm{z}$ 273. The fragment ions observed at $\mathrm{m} / \mathrm{z} 642$ and $\mathrm{m} / \mathrm{z} 628$ accounted for the loss of acetylated pentopyranoside and hexapyranoside respectively from the molecular ion peak. The loss of both acetylated sugar moieties gave a fragment at $\mathrm{m} / \mathrm{z} 370$. The aglycone fragment was observed at $\mathrm{m} / \mathrm{z} 286$. A retro DielsAlder fragmentation pattern was observed at $\mathrm{m} / \mathrm{z} 153$ and 121 leading to fragments $\left[\mathrm{A}_{1}+\mathrm{H}\right]$ and $\mathrm{B}_{2}{ }^{+}$which supported the two hydroxyl groups in ring- $\mathrm{A}$ and one hydroxyl group in ring-B. Other prominent sugar fragment ions appeared at $\mathrm{m} / \mathrm{z} 213,171,153,111,97,96$.

Enzymatic hydrolysis of the parent glycoside XI-5 gave conclusive evidences of the position of attachment of two sugars and nature of their linkage. Hydrolysis of XI- 5 with $\alpha$-rhamnosidase (containing $\alpha$-pectinase) gave L-rhamnose indicating $\alpha$-nature of sugar and a partial glycoside of (1c), which gave a bathochormic shift of $+60 \mathrm{~nm}$ with $\mathrm{NaOMe}$ in band I without a decrease in intensity (absent in glycoside). Thus showing that C-4' hydroxyl which was glycosylated in XI-5 had become free. The partial glycoside of XI-5 was identified as kaempferol-3-xyloside (1c), m.p., $224-26^{\circ} \mathrm{C}$ by UV diagnostic shift reagents and co-chromatography with authentic sample. ${ }^{14}$ Methylation of partial glycoside (1c- 5c) followed by hydrolysis with $2 \mathrm{~N}$ $\mathrm{HCl}$ gave a partial methyl ether (1d), m.p. $134-35^{\circ} \mathrm{C}$ characterized as $3-\mathrm{OH}$, 5,7,4'-trimethoxyflavone (kaempferol 5,7,4'-trimethyl ether) by spectral and chromatographic comparison with authentic sample. ${ }^{15}$ The methylated sugar were identified as 2,3,4-tri-O-methyl-xylose by $\mathrm{SiO}_{2}$ TLC according to Petek. ${ }^{16}$ This finally established that L-rhamnose was $\alpha$-linked at C-4' while D-xylose was $\beta$-linked at 3-position. Quantitave estimation of sugar by Somogyi copper micro method ${ }^{17}$ indicated the presence of two moles of sugar/mole of aglycone.

On the basis of above results, compound $\mathbf{X I - 5}$ was identified as Kaempferol3 - $\beta$-xylopyranoside-4'- $\alpha$-rhamnoside. To the best our knowledge it is being reported for the first time.

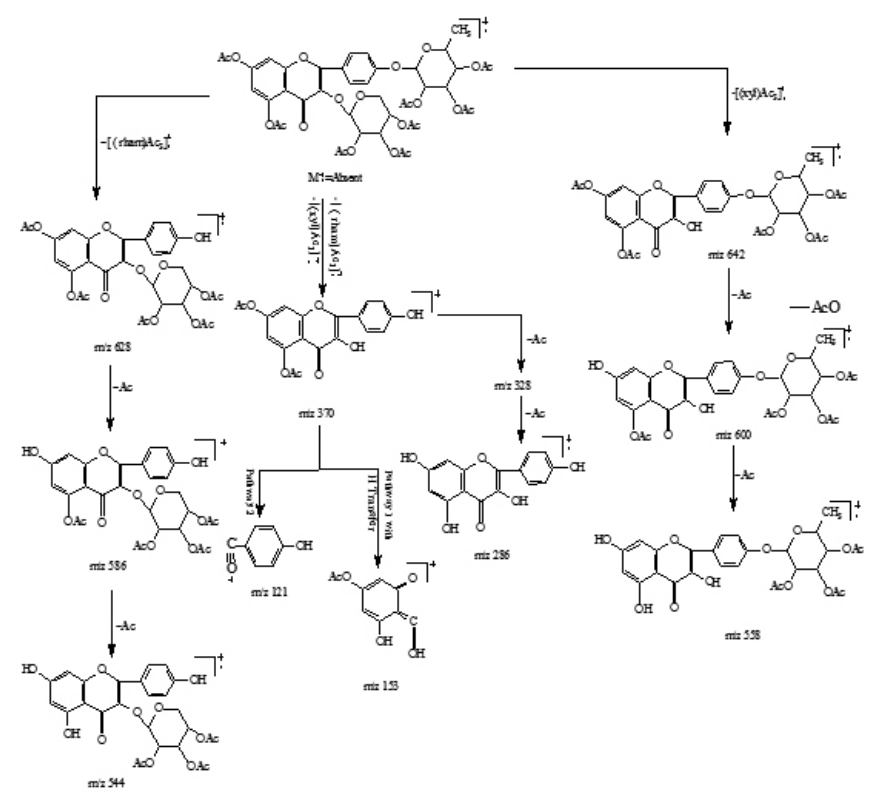

Scheme1. Mass fragmentation pattern of the compound XI-5 Ac.

The antimicrobial activity of aqueous and alcoholic extracts of Xylosma longifolium, extract was investigated against bacterial and fungal strains. It was seen that all the extracts exhibited a low, moderate or high activity against gram positive and fungal strains. The aqueous extract showed high activity against Staphylococcus aureus (IAO-SA-22) and Candida albican (IAO-109) and moderate activity against Bacillus subtilis (MTCC-121) and Trichoderma viridae (lab isolate). The alcoholic extract found to show high activity against Staphylococcus aureus (IAO-SA-22) and Candida albican (IAO109) and moderate activity against Bacillus subtilis (MTCC-121), Salmonella typhimurium (MTCC-98), Aspergillus brassicola.

Table.1 Antimicrobial activity of Xylosma longifolium aqueous and alcoholic extracts.

\begin{tabular}{|c|c|c|c|}
\hline Stains & $\begin{array}{c}\text { Aqueous } \\
\text { extract }\end{array}$ & $\begin{array}{c}\text { Alcoholic } \\
\text { extract }\end{array}$ & Standards \\
\hline $\begin{array}{c}\text { Staphylococcus aureus (IAO- } \\
\text { SA-22) }\end{array}$ & 11 & 14 & 20 \\
\hline $\begin{array}{c}\text { Escherichia coli (K-12) } \\
\text { Salmonella typhimurium } \\
\text { (MTCC-98) }\end{array}$ & -- & -- & 22 \\
\hline $\begin{array}{c}\text { Bacillus subtilis (MTCC-121) } \\
\text { Candida albican (IAO-109) }\end{array}$ & 10 & 7 & 18 \\
\hline $\begin{array}{c}\text { Fusarium oxysporum (lab } \\
\text { isolare) }\end{array}$ & -- & -- & 16 \\
\hline Aspergillus niger (lab isolate) & -- & -- & 20 \\
\hline $\begin{array}{c}\text { Trichoderma viridae (lab } \\
\text { isolate) }\end{array}$ & 7 & -- & 16 \\
\hline Aspergillus brassicola & -- & 8 & 18 \\
\hline
\end{tabular}

Low activity (1-5), moderate activity (6-10), high activity (11-15), very high activity (16-20), no activity (--)

\section{REFERENCES}

1 H.Y. Chadha, The wealth of India raw materials, XI, 11, (2003).

2 C.P. Khare, Indian Medicinal plants, An Illustrated Dictionary, Springer, 725, (2007)

3 P. Hanelt, Mansfeld Encyclopedia of Agricultural and Horticultural crop (Exceptornamentals), Springer, 3, 1374, (2001).

4 M. Parveen, R.M. Ghalib, R. Rehman, M. Ali, Hamdard Medicus, 3, 47, (2009).

5 A.T. Hiraoka, M. Masquakris, Chem. Pharm. Bull, 27, 3130, (1979).

6 T.J. Mabry, K.R. Markham, M.B Thomas, "The Systematic Identification of flovonoids", Springer, New York, (1970).

7 K. Tobinaga, Yoshimura, J. pharm. Soc., Japan, 79, 555, (1959).

8 T. Nakakoi, N. Morita, S. Nishino, J. Pharm. Soc. Japan, 77, 110, (1957).

9 C. pervez, M. Pauli, P.Bazerque, Acta Biol. Med. Exp, 15, 113, (1990).

10 I. Ahmad, A.Z. Beg, J. Ethnopharmacol, 74, 113, (2001).

11 T.A. Geissman, The chemistry of flavonoid compounds, Pergamon press, 72, (1962).

12 K.R. Markham, T.J. Mabry, J.B. Harborne, H. Mabry,Mabry, The flavonoids etds. London, Chapman\& Hall, 48, (1975).

13 F.E King, J.W. Clark-Lewis, W.F. Forbes, J. Chem.Soc., 2948, (1955).

14 N. Ishikura, S. Sato, Bot.Mag, 90, 83, (1977).

15 F.E. King, A. King, J. Chem. Soc., 1681, (950).

16 F. Petek, Bull. Soc. Chim. Fr., 263, (1965).

17 M. Somogyi, J. Biol.Chem., 19, 195, (1952). 